\title{
E-Book Based on Local Wisdom to Improve Students' Numeracy Skill: Is It Effective?
}

\author{
Irma Rachmah Hidayah ${ }^{1, *}$ Tri Atmojo Kusmayadi ${ }^{2,}$ Laila Fitriana $^{3}$ \\ ${ }^{1}$ Postgraduate of Mathematics Education, Faculty of Teacher Training and Education, Universitas Sebelas \\ Maret, Surakarta, Indonesia \\ ${ }^{2}$ Faculty of Mathematics and Natural Sciences, Universitas Sebelas Maret, Surakarta, Indonesia \\ ${ }^{3}$ Faculty of Teacher Training and Education, Universitas Sebelas Maret, Surakarta, Indonesia \\ *Corresponding author. Email: irmarhidayah@outlook.com
}

\begin{abstract}
21st-century technology in education makes it straightforward for teachers to support students for independent learning. Technology facilitates students to access information, create innovations, and increase student interest in learning. Previous studies proffered that better learning outcomes were achieved by students who used e-books than those with regular printed books. This quasi-experimental study tested the effectiveness of e-book based on local wisdom in improving students' numeracy skill. This study used a non-equivalent groups design. The sample was seventh-grade secondary school students. An experiment class comprised 30 students and a control class involved 32 students. The experimental class used the local wisdom-based e-book in learning mathematics. Meanwhile, the control class did not use the local wisdom-based e-book in learning mathematics. The two classes were taught the same lesson of social arithmetic. The sample selection used random cluster sampling. The employed instrument was a numeracy test for pretest and posttest. It was validated, tried out, and analyzed to determine the feasibility before the test. This study shows that the students' mean scores of the experimental class are greater than the control class. It was deduced that the use of e-book based on local wisdom is effective since it could improve students' numeracy skill.
\end{abstract}

Keywords: E-book, Effective, Learning media, Numeracy skill.

\section{INTRODUCTION}

The development of information technology has significant impacts on various aspects of life such as education, science, information flow, and communication [1]. The use of technology in education in the 21 st century makes it straightforward for teachers to support students to learn more independently [2]. Technology plays an essential role in facilitating students to access information, create innovations, and increase student interest in students' learning. Student enthusiasm in learning is an internal factor affecting learning achievement concerning individual desires or needs [3]. Individuals with a passionate interest in learning will have strong motivation [4]. It makes students more motivated in learning [3]. An example of a means that can increase students' motivation is learning media [4]. The learning media is a means of intermediary in the learning process [5]. It helps students understand the lesson [6]. Teachers are required to maximize the use of teaching media for developing learning concepts [7].

The use of electronic media serves as an effective teaching aid compared to non-electronic media [8]. In recent years, the development of electronic book (ebook) started a revolution in education [9]. E-books are interactive media to integrate audio, video, animation, and simulations enabling data presented to be more diverse than printed books [10]. E-books as an essential part of academic activities can be a solution in overcoming educational challenges [11]. The implementation of e-book in learning in various circumstances for their advantages and usefulness merits high-school and college students [12], including supporting learning, providing information, being a resource for students and researchers, and potentially decreasing the physical library use [13]. Previous studies stated that students who use e-books were better than those who only used PowerPoint or other aids [14]. 
Learning achievement affects 21 st-century basic literacy skills [15]. One of the basic literacy skills is numeracy skill. Numeracy skill is a term to identify knowledge, dispositions, abilities, and practices that require mathematics and statistics to manage and solve problems in various life situations [16]. Numeracy is not only related to mathematical skills but also statistical skills [17]. Numerical skills must be equipped from an early age since the skill is required in the 21st century [18]. In this research, numeracy is defined as analyzing, applying, and interpreting quantitative data in daily life problems requiring principal mathematical skills.

Studies related to numerical literacy skills are closely related to the culture of a society which is analyzed specifically in ethnomathematics-based research [19]. The implementation of local culture in learning has a constructive influence on responsible learning behavior [20]. This study tested the effectiveness of e-book based on local wisdom in improving students' numeracy skill. The e-book develops mathematical learning media that reinforce basic literacy, numeracy skill in social arithmetic material based on local wisdom. This research focused on Cirebon local wisdom since this study was conducted in Cirebon. The e-book was designed based on Cirebon students' characteristics. It provides the feature of interactive exercises problems. The feature aims to find out the mastery of students' competency towards the material that has been studied. The exercise problems in the e-book are designed like the Minimum Competency Assessment (AKM).

\section{METHOD}

This research is quasi-experimental. Quasiexperiment is a study that provides natural treatment to determine the effect of treatment [21]. Previous study describes the importance of quasi-experimental research in the field of education [22]. This study used a non-equivalent groups design since this study used a pretest and posttest in the experimental and control classes. The experimental class used local wisdombased e-book in learning mathematics. Meanwhile, the control class did not use local wisdom-based e-book in learning mathematics. The two classes were taught the same lesson of social arithmetic. The sample selection in this study used random cluster sampling since it was more practical than other sampling techniques such as random sampling and stratified sampling [23]. The sample in this study was seventh-grade secondary school students. The experiment class comprised 30 students and the control class involved 32 students. The total experiment and control class is 62 students. Table 1 summarizes the sample of demographic information in this study.
Table 1. The sample of demographic information

\begin{tabular}{|l|c|l|}
\hline \multicolumn{1}{|c|}{ Group } & Sample & \multicolumn{1}{|c|}{ Learning Media } \\
\hline Experiment & 30 & $\begin{array}{l}\text { E-book based on local } \\
\text { wisdom }\end{array}$ \\
\hline Control & 32 & $\begin{array}{l}\text { Non-E-book based on local } \\
\text { wisdom }\end{array}$ \\
\hline
\end{tabular}

The instrument employed was a numeracy test for pretest and posttest. The numeracy skill indicators used in this study were based on the Numerical Literacy Enrichment Guidebook from the Ministry of Education and Culture [24]. There are three indicators 1) using varied numbers and symbols associated with principal mathematics to answer practical problems in several settings of everyday life, 2) investigating data presented in graphs, tables, and charts; and 3) deciphering the analysis results to augur and make conclusions. Three experts validated the test instrument as a validator. After the instrument was declared valid, the reliability test using Cronbach's Alpha was carried out since the test used was in an essay form.

Before the treatment in the experimental class using a local wisdom-based e-book, the students of the experimental and control classes were given a pretest. The pretest results were tested statistically to determine whether the experimental and control classes were equal. Duration of an intervention using the e-book in the experimental class was four weeks after the students were given the pretest. The learning treatment was carried out in four meetings in the experimental class. After it was completed, the students of those classes were given a posttest. The posttest results from both classes were tested statistically to test the effectiveness of the e-book. Statistical and reliability calculations are computed using SPSS 25.

\section{RESULTS AND DISCUSSION}

Table 2. Difficulty level and discriminating power index of pretest

\begin{tabular}{|l|c|c|c|c|c|}
\hline Item Number (N) & N1 & N2 & N3 & N4 & N5 \\
\hline Difficulty level & 0.687 & 0.550 & 0.500 & 0.450 & 0.312 \\
\hline $\begin{array}{l}\text { Discriminating } \\
\text { power index }\end{array}$ & 0.726 & 0.660 & 0.609 & 0.834 & 0.608 \\
\hline
\end{tabular}

The validation and trial results stated that the local wisdom-based e-book was valid and practical to be used. It had gone through validation by media experts and lesson experts to validate the validity of the ebook. It had also been tested on teachers and students to assess the practicality of the e-book. 
Table 2 shows that the five pretest items of the numeracy skill test had discriminating power index and difficulty level with good categories. The reliability coefficient of the numeracy pretest was 0.718. Thus, the pretest instrument was reliable because $r_{11} \geq 0.7$.

Table 3. Difficulty level and discriminating power index of posttest

\begin{tabular}{|l|c|c|c|c|c|}
\hline Item Number (N) & N1 & N2 & N3 & N4 & N5 \\
\hline Difficulty level & 0.487 & 0.675 & 0.650 & 0.350 & 0.650 \\
\hline $\begin{array}{l}\text { Discriminating } \\
\text { power index }\end{array}$ & 0.509 & 0.638 & 0.682 & 0.836 & 0.728 \\
\hline
\end{tabular}

Table 3 shows that the five posttest items of the numeracy skill test have discriminating power index and a difficulty level with good categories. The reliability coefficient of the numeracy posttest was 0.703 . Thus, the posttest instrument was reliable because $r_{11} \geq 0.7$.

Table 4. Mean score

\begin{tabular}{|l|l|l|}
\hline \multirow{2}{*}{ Group } & \multicolumn{2}{|c|}{ Mean Score } \\
\cline { 2 - 3 } & Pretest & Post-test \\
\hline Experiment & 52.833 & 69.750 \\
\hline Control & 49.765 & 60.000 \\
\hline
\end{tabular}

Table 4 shows the mean score of the experimental class is greater than the control class, (16.917>10.235). It indicates descriptively that there is a difference between the mean of the given pretest and posttest. It shows differences in numeracy skills between students who used a local wisdom-based ebook and students who did not use a local wisdombased e-book.

Table 5. Normality test for pretest data

\begin{tabular}{|l|l|l|c|l|}
\hline \multirow{2}{*}{} & \multirow{2}{*}{ Group } & \multicolumn{3}{|c|}{ Kolmogorov-Smirnov } \\
\cline { 3 - 5 } Score & & Statistic & df & Sig. \\
\cline { 3 - 5 } & Exp_Pre & 0.143 & 30 & 0.121 \\
\cline { 2 - 5 } & Con_Pre & 0.163 & 32 & 0.030 \\
\hline
\end{tabular}

A normality test is used to determine whether the data is normally distributed. In this study, the normality test was carried out using the KolmogorovSmirnov for the pretest of the experimental class and the control class. The normality test using Kolmogorov-Smirnov was used since the number of samples from this study was more than 50 [25]. A data is normally distributed if the significance value is more than $\alpha=0.05$.

Table 5 presents the significant score of the pretest in the experimental class was greater than $\alpha$ of Sig $=$ $0.121>\alpha=0.05$. The data is declared to be a normal distribution. Meanwhile, the pretest significance value of the control class is less than $\alpha$ of Sig $=0.030<$ $\alpha=0.05$. The data is not distributed normally. The data should be made normally distributed. The transformation of the histogram is moderate positive skewness. Thus, the form of data transformation used the square root [26]. Table 6 is a summary of the normality test that has been transformed using the square root.

Table 6. Normality test for transformed pretest data

\begin{tabular}{|c|l|l|c|c|}
\multirow{2}{*}{ Group } & \multicolumn{3}{|c|}{ Kolmogorov-Smirnov } \\
\cline { 3 - 5 } & & Statistic & df & Sig. \\
\hline \multirow{2}{*}{ Score } & Exp_Pre & 0.150 & 30 & 0.085 \\
\cline { 2 - 5 } & Con_Pre & 0.152 & 32 & 0.060 \\
\hline
\end{tabular}

Table 6 shows the significant value of the pretest of the experimental and control classes. They are more significant than $\alpha$ of Sig $=0.085>\alpha=0.05$ and Sig $=0.060>\alpha=0.05$. Therefore, the pretest of the experimental and control classes is normally distributed. After the normality test, the data were tested for homogeneity. The homogeneity test in this study employed Levene's test. It compares the variance of the experimental and control classes that have been transformed into normally distributed data. Table 7 displays the homogeneity test results.

Table 7. Homogeneity test for pretest data

\begin{tabular}{|l|l|c|c|}
\hline \multicolumn{2}{|c|}{} & \multicolumn{2}{|c|}{ Lavene's Test } \\
\cline { 2 - 4 } Score & Equal variances assumed & 1.386 & 0.244 \\
\cline { 2 - 4 } & $\begin{array}{l}\text { Equal variances not } \\
\text { assumed }\end{array}$ & & \\
\hline
\end{tabular}

Table 7 presents that the significance value is more significant than $\alpha$ of Sig $=0.244>\alpha=0.05$. It can be concluded that the variances of the pretest of both classes are homogeneous.

The t-test was carried out after the normality and homogeneity were fulfilled. It was to test the class balance. It was employed to test whether the experimental and control classes were in balance before receiving treatment. The data used is the mean score of the pretest of numeracy skill. Table 8 shows the t-test for pretest data.

Table 8. T-test for pretest data

\begin{tabular}{|l|c|c|c|}
\hline \multirow{2}{*}{ Group } & \multicolumn{3}{|c|}{ t-test } \\
\cline { 2 - 4 } & $\mathrm{t}$ & $\mathrm{df}$ & Sig. (2 tailed) \\
\hline Experiment & 1.384 & 60 & 0.172 \\
\hline Control & 1.389 & 59.832 & 0.170 \\
\hline
\end{tabular}


Table 8 shows Sig. (2 tailed) $>0.05$. The conclusion is that both experimental and control classes have a balanced population. It shows that both classes have the same initial ability.

The effectivity of e-book was tested by the t-test. It was carried out after the normality and homogeneity were fulfilled. The data used is the mean score of the posttest of numeracy skill.

Table 9. Normality test for posttest data

\begin{tabular}{|l|l|c|c|l|}
\hline \multirow{2}{*}{} & \multirow{2}{*}{ Group } & \multicolumn{3}{|c|}{ Kolmogorov-Smirnov } \\
\cline { 3 - 5 } Score & & Statistic & Df & Sig. \\
\cline { 3 - 5 } & Exp_Post & 0.179 & 30 & 0.015 \\
\cline { 2 - 5 } & Con_Post & 0.102 & 32 & 0.200 \\
\hline
\end{tabular}

Table 9 exposes the significant score of the posttest of the experimental class is less than Sig $=0.015<$ $\alpha=0.05$. The data is not normally distributed. Meanwhile, the significance value of the control class posttest is greater than $\alpha$ of Sig $=0.200>\alpha=0.05$. Thus, the data is distributed normally. The transformation of the histogram graph is substantial positive skewness. So, the form of data transformation uses logarithms [26]. Table 10 summarizes the normality test of the data that has been transformed using the logarithms.

Table 10. Normality test for transformed posttest data

\begin{tabular}{|l|l|c|c|c|}
\hline \multirow{2}{*}{} & \multirow{2}{*}{ Group } & \multicolumn{3}{|c|}{ Kolmogorov-Smirnov } \\
\cline { 3 - 5 } & & Statistic & Df & Sig. \\
\hline \multirow{2}{*}{ Score } & Exp_Post & 0.156 & 30 & 0.059 \\
\cline { 2 - 5 } & Con_Post & 0.126 & 32 & 0.200 \\
\hline
\end{tabular}

Table 10 shows the significant score of the posttest in the experimental and control classes which are greater than $\alpha$ of Sig $=0.059>\alpha=0.05$ and Sig $=$ $0.200>\alpha=0.05$. The posttest data for the experimental and control classes are normally distributed.

After the normality test, the data were tested for homogeneity. Table 11 depicts the results of the homogeneity test.

Table 11. Homogeneity test for posttest data

\begin{tabular}{|l|l|c|c|}
\hline \multicolumn{2}{|c|}{} & \multicolumn{2}{|c|}{ Lavene's Test } \\
\cline { 3 - 4 } Score & Equal variances assumed & 1.197 & Sig. \\
\cline { 2 - 4 } & $\begin{array}{l}\text { Equal variances not } \\
\text { assumed }\end{array}$ & & \\
\hline
\end{tabular}

Table 11 shows that the significance value is more significant than $\alpha$ of $\mathrm{Sig}=0.278>\alpha=0.05$. Therefore, it can be summed up that both classes' posttest data variances are homogeneous.

After the normality and homogeneity were fulfilled, the t-test was carried out. It was to test the effectivity of e-book. The data used is the mean score of the posttest of numeracy skill. Table 12 shows the t-test for posttest data.

Table 12. T-test for posttest data

\begin{tabular}{|l|c|c|c|}
\hline \multirow{2}{*}{ Group } & \multicolumn{4}{|c|}{ t-test } \\
\cline { 2 - 4 } & $\mathrm{t}$ & $\mathrm{df}$ & Sig. (2 tailed) \\
\hline Experiment & 3.499 & 60 & 0.001 \\
\hline Control & 3.530 & 57.488 & 0.001 \\
\hline
\end{tabular}

Table 12 exhibits that the significance value (twotailed) in the experimental and control classes are 0.001 . Then the significance value (one-tailed) is 0.0005 . The significance value is less than $\alpha$ of Sig. (one-tailed) $<0.05$. It presents that the mean score of the numeracy skill of the experimental class is greater than the mean score of the control class. It can be decided that the use of e-book based on local wisdom is effective since it could improve students' numeracy skill.

The research results are compatible with previous researches that learning using e-books is more effective than learning that does not use e-books [9], [14]. The use of learning media based on local culture also improves student achievement [27]. Learning that integrates local culture is effective and can be a learning innovation to enhance literacy skills [28]. One of the basic literacy skills that must be mastered is numeracy skill. Applying numbers, data, and mathematical symbols is related to numeracy skill [16]. The skill can be used to help solve the problems of human life [18]. Numeracy skill plays an essential role in the students' cognitive [16]. Previous study stated that there are three critical aspects of creating a supportive environment for numeracy skill. They are 1) the demands for numeracy skill, 2) opportunities to apply numeracy skill, and 3) the support and resources offered as well as solutions to the barriers that hinder numeracy skill [29].

\section{CONCLUSION}

This study shows a difference in numeracy skill between the experimental and control classes. It presents that the students' mean scores of the experimental class are greater than the control class. It was deduced that the use of e-book based on local wisdom is effective since it could improve students' 
numeracy skill. Mathematics teachers need to apply the e-book in the classroom to enhance numeracy skill.

This study tested the effectiveness of e-book based on local wisdom in improving students' numeracy skill. The research results can be applied in mathematics learning to enhance numeracy skill. This study utilized an e-book based on Cirebon local wisdom using numeracy skill indicator. Further research is needed to develop, apply, and investigate other media by implementing numeracy skill indicators and local wisdom values in mathematics learning to all levels of education with different mathematics material to improve students' numeracy.

\section{REFERENCES}

[1] A. H. Nasution, F. R. Dongoran, Johnson, and D. H. Syah, "The Effectiveness of Using Online Learning Methods Based on Video Conference in the Course of an Introduction to Microeconomics," Adv. Econ. Bus. Manag. Res., vol. 163, pp. 180-185, 2020.

[2] D. Domenech, M. Sherman, and J. L. Brown, Personalizing 21st Century Education: A framework for student success. San Francisco: Jossey-Bass, 2016.

[3] C. Y. C. Yeh, H. N. H. Cheng, Z.-H. Chen, C. C. Y. Liao, and T.-W. Chan, "Enhancing Achievement and Interest in Mathematics Learning Through Math-Island," Res. Pract. Technol. Enhanc. Learn., vol. 14, no. 5, pp. 119, 2019.

[4] M. S. Anwar, Choirudin, E. F. Ningsih, T. Dewi, and A. Maseleno, "Developing an Interactive Mathematics Multimedia Learning Based on Ispring Presenter in Increasing Students' Interest in Learning Mathematics," Al-Jabar J. Pendidik. Mat., vol. 1, no. 1, pp. 135-150, 2019.

[5] C. H. Nabilah, A. Sesrita, and I. Suherman, "Development of Learning Media Based on Articular Storylines," Indones. J. Appl. Res., vol. 1, no. 2, pp. 80-85, 2020.

[6] G. N. S. Agustika, "The Influence of Augmented Reality-Based Learning Media on the Students' Achievement of Mathematics," Adv. Soc. Sci. Educ. Humanit. Res., vol. 540, pp. 47-56, 2020.

[7] Masniladevi, R. C. I. Prahmana, Y. Helsa, and M. Dalais, "Teachers' ability in using math learning media,” J. Phys. Conf. Ser. 943 012059, pp. 1-5, 2017.

[8] S. Areerachakul, "Using Electronic Medias for Science Mathematic and English in School under Office of the Basic Education Commission,
Thailand," Procedia - Soc. Behav. Sci., vol. 197, pp. 1558-1563, 2015.

[9] C. S. Lai, "Integrating E-books into Science Teaching by Preservice Elementary School Teachers," J. Educ. Sci. Environ. Heal., vol. 2, no. 1, pp. 57-66, 2016.

[10] Asrowi, A. Hadaya, and M. Hanif, "The impact of using the interactive e-book on students' learning outcomes," Int. J. Instr., vol. 12, no. 2, pp. 709-722, 2019.

[11] B. Casselden and R. Pears, "Higher education student pathways to e-book usage and engagement, and understanding: Highways and cul de sacs," J. Librariansh. Inf. Sci., vol. 52, no. 2, pp. 601-619, 2020.

[12] A. G. Almekhlafi, "The effect of E-books on Preservice student teachers' achievement and perceptions in the United Arab Emirates," Educ. Inf. Technol., vol. 26, no. 1, pp. 1001-1021, 2020.

[13] D. E. Frederick, “On eBooks in academic libraries: An article based on a presentation at the library 2.014 conference," Libr. Hi Tech News, 2015.

[14] C. C. Hsiao, M. M. Tiao, and C. C. Chen, "Using interactive multimedia e-Books for learning blood cell morphology in pediatric hematology," BMC Med. Educ., vol. 16, no. 1, pp. 1-8, 2016.

[15] Y. Chen et al., "The influence of school entry skills in literacy and numeracy on the science achievement of fourth grade students and schools in Asian regions," Eurasia J. Math. Sci. Technol. Educ., 2020.

[16] V. Geiger, M. Goos, and H. Forgasz, "A rich interpretation of numeracy for the 21 st century: a survey of the state of the field," ZDM Math. Educ., vol. 47, pp. 531-548, 2015.

[17] I. Gal, A. Grotlüschen, D. Tout, and G. Kaiser, "Numeracy, adult education, and vulnerable adults: a critical view of a neglected field," $Z D M$ - Math. Educ., vol. 52, no. 3, pp. 377-394.

[18] K. Gravemeijer, M. Stephan, C. Julie, F. L. Lin, and M. Ohtani, "What Mathematics Education May Prepare Students for the Society of the Future?," Int. J. Sci. Math. Educ., 2017.

[19] N. E. Hendrawati, N. Muttaqin, and E. Susanti, "Etnomatematika: Literasi Numerasi Berdasarkan Bahasa pada Suku Kowai Kabupaten Kaimana,” 2019

[20] O. F. Nugroho, A. Permanasari, H. Firman, and Riandi, "STEM Approach Based on Local 
Wisdom to Enhance Sustainability Literacy," 2nd Int. Conf. Sci. Math. Environ. Educ., pp. 1$5,2019$.

[21] J. Green, "Points of Intersection between Randomized Experiments and QuasiExperiment," Ann. Am. Acad. Pol. Soc. Sci., vol. 628, no. 1, pp. 97-111, 2010.

[22] M. Delucchi, “Using a Quasi-Experimental Design in Combination with Multivariate Analysis to Assess Student Learning," J. Scholarsh. Teach. Learn., vol. 19, no. 2, pp. 1$15,2019$.

[23] A. S. Singh and M. B. Masuku, "Sampling Techniques \& Determination of Sample Size in Applied Statistics Research: An Overview," Int. J. Econ. Commer. Manag., vol. 2, no. 11, pp. 122, 2014.

[24] Kementerian Pendidikan dan Kebudayaan [Ministry of Education and Culture of the Republic of Indonesia], "Materi pendukung literasi Numerasi [Numerical Literacy Enrichment Guidebook],” 2017.

[25] P. Mishra, C. M. Pandey, U. Singh, C. Sahu, and A. Keshri, "Descriptive Statistics and Normality Tests for Statistical Data," Ann. Card. Annaesthesia, vol. 22, no. 1, pp. 67-72, 2019.

[26] S. Manikandan, "Data Transformation," J. Pharmacol. Pharmacother. 1(2), 126-127, vol. 1, no. 2, pp. 126-127, 2010.

[27] H. Pujiastuti, D. Suvati, R. Haryadi, and I. Marethi, "Development of mathmodule based on local wisdom and 21stcentury skills: linear equation system," IOP Conf. Ser. J. Phys. Conf. Ser., vol. 1480, pp. 1-8, 2020.

[28] S. Suryanti, N. Mariana, Y. Yermiandhoko, and W. Widodo, "Local wisdom-based teaching material for enhancing primary students' scientific literacy skill," Local wisdom-based Teach. Mater. enhancing Prim. students' Sci. Lit. Ski., vol. 8, no. 1, pp. 96-105, 2020.

[29] J. Evans, K. Yasukawa, D. Mallows, and B. Creese, "Numeracy skills and the numerate environment: Affordances and demands," 2017. 